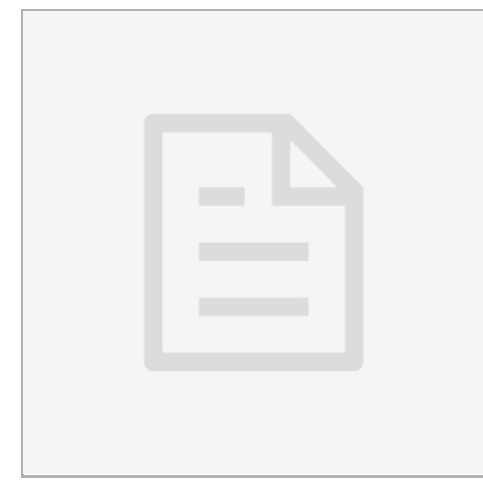

APR 15, 2019

\title{
(3) Centrifuge the whole blood to separate red blood cells
}

George Lykotrafitis ${ }^{1}$

${ }^{1}$ University of Connecticut

(

George Lykotrafitis

\section{ABSTRACT}

Centrifuge the whole blood in order to obtain the red blood cells.

\section{MATERIALS}

Human whole blood, centrifuge, centrifuge tubes.

\section{DOI:}

dx.doi.org/10.17504/protocol s.io.zzwf77e

Protocol Citation: George Lykotrafitis 2019. Centrifuge the whole blood to separate red blood cells. protocols.io https://dx.doi.org/10.17504/p rotocols.io.zzwf77e

License: This is an open access protocol distributed under the terms of the Creative Commons Attribution License, which permits unrestricted use, distribution, and reproduction in any medium, provided the original author and source are credited

Protocol status: Working We use this protocol in our group and it is working.

Created: Apr 11, 2019

Last Modified: Apr 15, 2019

\section{PROTOCOL integer ID:}

22294

1 Centrifuge the whole blood using the parameters: $500 \times \mathrm{g}, 4^{\circ} \mathrm{C}$, and $5 \mathrm{~min}$. 
2 Remove the plasma and buffy coat.

3 Add the same volume of Alsever's solution as the remaining blood components.

4 Centrifuge again using the parameters: $500 \times \mathrm{g}, 4{ }^{\circ} \mathrm{C}$, and $5 \mathrm{~min}$.

5 Remove the top layer.

6 Add the same volume of Alsever's solution as the remaining blood components.

7 Centrifuge a third time using the parameters: $500 \times \mathrm{g}, 4^{\circ} \mathrm{C}$, and $5 \mathrm{~min}$.

8 Remove the top layer.

9 Add the same volume of Alsever's solution as the remaining blood component - red blood cells, and store at $4{ }^{\circ} \mathrm{C}$ for up to 7 days. 